\title{
Physical and Mechanical Properties of Three-layer Particleboards Bonded With UF and UMF Adhesives ${ }^{1}$
}

\author{
Apri Heri Iswanto (D ${ }^{2, \dagger} \cdot$ Janrahman Simarmata $^{2} \cdot$ Widya Fatriasari $^{3} \cdot$ \\ ${\text { Irawati } \text { Azhar }^{2} \cdot \text { Tito Sucipto }^{2} \cdot \text { Rudi Hartono }}^{2}$
}

\begin{abstract}
A low dimensional stability and poor bending strength properties were main problems in particleboard manufacturing. The objective of this research was to evaluate the effect of mixed wood species and urea-formaldehyde (UF) or urea-melamine-formaldehyde (UMF) resins on the physical and mechanical properties of three-layer particleboards. The ratio of face/core/back layer was $1: 2: 1$. The resin content of $12 \%$ for both UF resins and UMF resins (UF/MF $=70 / 30 \% \mathrm{w} / \mathrm{w})$ was used. The results of this study showed that the utilization of S.mahagony shaving using both UF and UMF resins caused a decrease in the thickness swelling and water absorption of the boards. Thickness swellings of particleboard made of Sengon/Sengon/Sengon (SSS), Mahogany/Mahogany/Mahogany (MMM), Sengon/Mahogany/Sengon (SMS), and Mahogany/Sengon/Mahogany (MSM) were in the range of $23 \%, 12 \sim 16 \%, 14 \sim 16 \%$, and 13 21\%, respectively. The board bonded with UMF resin demonstrated better dimensional stability than that bonded with UF resin alone. Modulus of elasticity (MOE) and modulus of rupture (MOR) of particleboards made of S. mahagony shaving in the surface layer in both MMM and MSM boards were better than those of the SSS and SMS. MOE of MMM and MSM board was in the ranges of 24,000 to $26,000 \mathrm{~kg} \cdot \mathrm{cm}^{-2}$ and 18,000 to $21,000 \mathrm{~kg} \cdot \mathrm{cm}^{-2}$ respectively. Meanwhile, the MOR of board was in the ranges of 200 to $240 \mathrm{~kg} \cdot \mathrm{cm}^{-2}$ and 190 to $228 \mathrm{~kg} . \mathrm{cm}^{-2}$, respectively.
\end{abstract}

Keywords : three layer particleboards, wood species combination, UF and MF mixture, physical and mechanical properties

\section{INTRODUCTION}

Forest degradation causes in decreasing the wood supply from natural forest. The great problem in Indonesian wood processing is the lack of wood as raw materials. This situation caused some of wood industries such as plywood and sawn timber industries is forced to stop to operate. In this situation, one of wood industries that can survive is particleboard industry. In their processing, the good wood quality is not required. These industries can uti-

1 Date Received January 27, 2017, Date Accepted October 30, 2017

2 Department of Forest Product, Faculty of Forestry, Universitas Sumatera Utara, Padang Bulan, Medan 20155, Indonesia

3 Research Center for Biomaterials LIPI, Bogor, Indonesia

† Corresponding author: Apri Heri Iswanto (e-mail: apriheri@yahoo.com, ORCID: 0000-0002-4243-1429) 
lize raw material from wood and non-wood included waste types. Wood shavings, one of waste types could be found easily in sawmill industries. Therefore, they had a high potency for particleboard raw materials. They could be defined as small particle with uncertainly size from wood shaving process and usually had thin curly formed in varied thickness (Bowyer et al., 2003).

A low dimensional stability and strength properties are well known as main problems on particleboard production. Many researchers had attempted to overcome those problems. Acetylation, paraffin methods, particle pre-treatment (Iswanto et al., 2010), particleboard post-treatment (Iswanto et al., 2017) had been performed to improve its dimensional stability. Utilization of wood combination of oriented strand board (OSB) and particleboards can improve the bending properties of board (Febrianto et al., 2010; Hidayat et al., 2011; Iswanto et al., 2012).

In this study, particleboard was made in 3 layers. Maloney (1993) explained that the three-layer particleboard could make from different particle size. The surface layer had a smaller or fine size, while the particle size of core layer had larger or coarse size. To obtain the optimal strength, larger proportion of adhesive in the surface layer was proposed. Yusoff et al. (2014) focused on the different combination wood density species to obtain the best physical and mechanical properties. Febrianto et al. (2010) also used combination of different wood density species for OSB. The strand com- bination using lower and higher wood density improved the dimensional stability and bending strength of boards. Addition of high quality material as surface layer into low quality material of board had improved board strength (Rofii et al., 2013; Iswanto et al., 2016).

This research was to improve the dimensional stability and mechanical properties of particleboard by combining UF and MF adhesive. The effect of Mahogany and Sengon wood shaving combination was also observed. These wood species were widely used in the wood industries in Medan, North Sumatera, Indonesia. Huge waste is produced from these industries. Mahoni wood has higher density compared to sengon wood. The densities of Mahogany and sengon wood were 0.6 and $0.32 \mathrm{~g} . \mathrm{cm}^{3}$ (Pandit et al., 2011), respectively.

\section{MATERIALS and METHODS}

\subsection{Materials}

The Mahogany (Swietenia mahagony) and Sengon (Paraserianthes falcataria) wood shavings were collected from wood sawmill in Medan, North Sumatra, Indonesia. Specimens were oven dried to the moisture content of $5 \%$. Urea Formaldehyde (UF) and Melamine Formaldehyde (MF) were used as resin adhesives with the resin content of $12 \%$.

\subsection{Particleboard Manufacturing}

Particleboards were produced with the size of $25 \times 25 \mathrm{~cm}^{2}$ with the density of $0.7 \mathrm{~g} . \mathrm{cm}^{-3}$, and 
the thickness of $1 \mathrm{~cm}$, respectively. Particles and adhesive were mixed using rotary mixer, in which UF resin was added followed by MF resin. Adhesive content of $12 \%$ for UF and UMF resin. Wood shavings were composed with three layers, namely, Sengon/Sengon/Sengon (SSS), Mahogany/Mahogany/Mahogany (MMM), Sengon/Mahogany/Sengon (SMS), and Mahogany/ Sengon/Mahogany (MSM). The ratio of face/ core/back layer was $1: 2: 1$. The mat then was pressed at the temperature of $130^{\circ} \mathrm{C}$ and at the pressure of $25 \mathrm{~kg} \cdot \mathrm{cm}^{-2}$ for $10 \mathrm{~min}$. Furthermore, the boards were conditioned for seven days at room temperature.

\subsection{Determination of Vertical Density Distribution}

Samples with dimension of $2 \times 2 \mathrm{~cm}^{2}$ were weighed to determine the initial density. Previously, samples were sanded and weighed to adjust the thickness of $1 \mathrm{~mm}$ to center of boards.

\subsection{Determination of Physical and Mechanical Properties}

The physical and mechanical parameters to be measured of the boards consisted of air-dry density, moisture content (MC), water absorption (WA), thickness swelling (TS), modulus of rupture (MOR) and modulus of elasticity (MOE) in bending, and internal bond (IB). The sample preparation and method to evaluate parameters were referred to JIS A 5908 (2003).

\subsection{Data Analysis}

Completely randomized design in triplicates for physical and mechanical properties was analyzed by analysis of variance (ANOVA). The significant differences were determined using Duncan's Multiple Range Tests (DMRT).

\section{RESULTS and DISCUSSIONS}

\subsection{Particle Geometry}

The Slenderness ratio (SR) and aspect ratio (AR) were calculated based on the ratio of particle length to particle thickness and particle length to particle width, respectively (Maloney, 1993). The SR of mahogany and sengon wood shaving were 153 and 136 respectively, while AR were 8.5 and 6.1 respectively. The higher SR caused better contact area and mechanical properties of board, and less binder consumption of board (Moslemi, 1974).

\subsection{Vertical Density Distribution}

Vertical density distribution of board was showed in Fig. 1 and 2. Wave pattern in vertical density was resulted by mixed wood shaving in particleboard. The density distribution of homogenous wood constituent in particleboard showed flat pattern from surface to core layer. Febrianto et al. (2010) stated that the density profile became steeper when lower density strand was used for core layer in oriented strand board (OSB). Similar trend was also occurred in homogenous strand used in OSB. On 
Apri Heri Iswanto $\cdot$ Janrahman Simarmata $\cdot$ Widya Fatriasari - Irawati Azhar - Tito Sucipto $\cdot$ Rudi Hartono

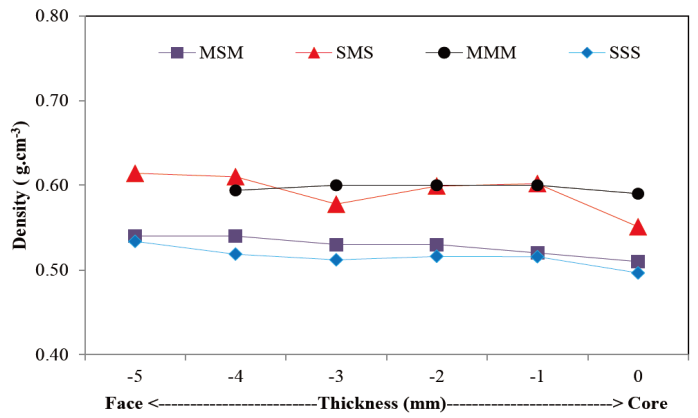

Fig. 1. Vertical density distribution of particleboard bonded with UF adhesive.

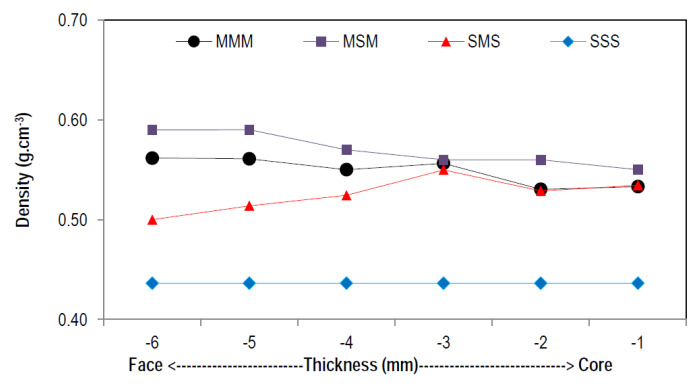

Fig. 2. Vertical density distribution of particleboard bonded with UF-MF mixture adhesives.

the other hand, the density profile became more uniform when higher density strands used as core layer of OSB. The different phenomenon was occurred in present study. It might be due to particle type and random orientation of wood shavings. Overall, the vertical density distribution in particleboard showed that the surface layer of board had higher density than that of others. In the particleboard manufacturing, surface layer had higher pressure and heat temperature compared to the core layer. During hot pressing, the interaction of heat, moisture content and pressure increased non-uniform deformation of the elements. It resulted variation of density distribution along with the thickness

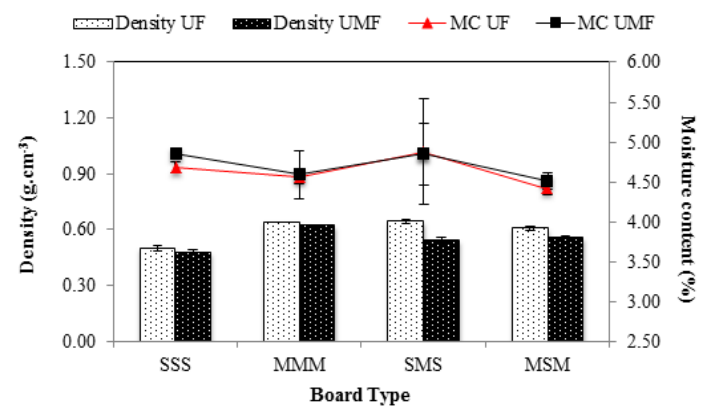

Fig. 3. Density and moisture content of particleboards.

direction of board (Winistrofer et al., 2000).

\subsection{Physical Properties}

\subsubsection{Density and Moisture Content (MC)}

Density and MC of board were showed in Fig. 3. Density of particleboard ranged 0.48 to 0.64 g. $\mathrm{cm}^{-3}$ with SSS board had the lowest density. Overall, the UF boards resulted higher density than the UMF boards. Overall, the presence of mahogany wood resulted higher density. Maloney (1993) and Kelly (1977) stated that wood species, wood density, particle size, particle MC, pressing condition, type and level of adhesive affeced particleboard qualities.

The density of board was lower than the target density of $0.75 \mathrm{~g} . \mathrm{cm}^{-3}$. Spring back of board during pressing and swelling of the board during conditioning process might cause it. The thickness of board exceeded from the thickness target of $1.00 \mathrm{~cm}$ after conditioning. MMM board has higher density than that of SSS board. It is presumed that mahogany wood with higher specific gravity than that of sengon wood will result lower spring back after conditioning. On the other hand, weight loss of 
particle during blending process could also affect low density of board. The similar finding had been stated by Bufalino et al. (2012).

Statistical analysis showed that all board types (UF and UMF resin) had significant differences on density. For UF resin, DMRT analysis showed that SSS board type was different significantly compared to others. Meanwhile, SSS, MMM and SMS did not have significant differences. Similar trend was also found on UMF resin. Overall, the density of board had met JIS A 5908 (2003) having requirement of density of 0.40 to $0.90 \mathrm{~g} . \mathrm{cm}^{-3}$ (JSA, 2003).

The board qualities were determined by MC of raw materials. High MC of materials will cause blowing and blister of particleboard. Maloney (1993) stated that MC of raw material up to $6 \%$ for UF caused blister in product. Furthermore, the variation of this initial MC determined particleboard MC. Garay et al. (2009) stated that wood particles having resistance to MC would result better dimensional stability of board.

MC of particleboard ranged 4.41 to $4.85 \%$ (Fig. 3). The highest and the lowest MC were resulted by SMS and MSM boards, respectively. The utilization of mahogany wood for surface layer resulted lower $\mathrm{MC}$ compared to sengon MC. And it could reduce hygroscopic properties of board during conditioning process. Statistical analysis showed that all board types for UF and UMF resin did not differed significantly on MC. Over all, the MC of boards was below to JIS A 5908 (2003) that require MC of 5 to $13 \%$ (JSA, 2003).

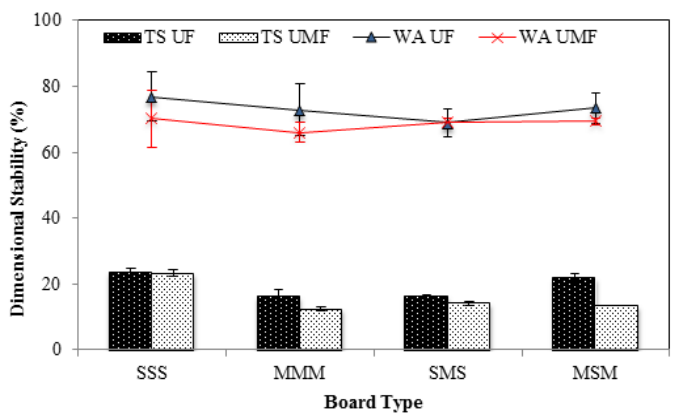

Fig. 4. Thickness swelling and water absorption of particleboards.

\subsubsection{Thickness Swelling (TS) and Water Absorption (WA)}

According to the Fig. 4, TS of particleboards ranged 12.53 to $23.61 \%$. The highest and the lowest TS of boards were resulted by SSS and MMM boards, respectively. Sengon particleboards resulted higher TS than that of mahogany affected by their specific gravity of wood. Sengon had low specific gravity resulting high compression ratio (CR). High $\mathrm{CR}$ caused increase of TS and WA (Febrianto et al., 2010).

Fig. 4 also shows that mahogany wood shaving combined with sengon shaving in UF board can improve the TS of board. The similar trends were also found on UMF board. On the other hand, specific gravity and wood density were important factor determining TS. The higher density resulted the better of inter-particle contact to improve particle bonding with adhesive. It resulted lower TS (Bufalino et al., 2012). Hsu (1987) stated TS value was determined by reversible swelling properties of wood, spring back of board, and furnish separation. Furthermore, TS was also affected 
by adhesive level and its distribution, furnish $\mathrm{MC}$, adhesive compatibility, and chemical component of furnish (Bektas et al., 2005).

Statistical analysis showed that UF and UMF boards had significant difference on TS. DMRT analysis of UF showed that SSS boards differed significantly with others. Similar trend was also found on UMF board. Overall, TS of board had met JIS A 5908 (2003) standard yet. The requirement of TS is less than 12\% (JSA, 2003).

Similar with TS, WA also was affected by density, adhesive, and wood species. High board density will result low WA. Fig. 4 showed that particleboard WA was 66.06 to $76.88 \%$. The highest and the lowest WA were resulted by SSS and MMM boards, respectively. Sengon particleboard resulted higher WA than that of mahogany. It was influenced by specific gravity of wood and board density. Utilization of UF adhesive affected WA of board classified into high WA. UF was only for interior application in order to increase WA of board (Iswanto et al., 2013).

Similar trend of TS was also showed by WA, mahogany wood combined with sengon wood shaving is able to decrease WA. Statistical analysis showed that all UF boards were not significantly different to TS. Meanwhile for UMF, all boards had significant differences to TS. DMRT analysis showed that SSS boards were significantly different with MMM and MSM, however they were not different significantly with SMS boards. WA had not required by JIS A 5908 (2003) standard.

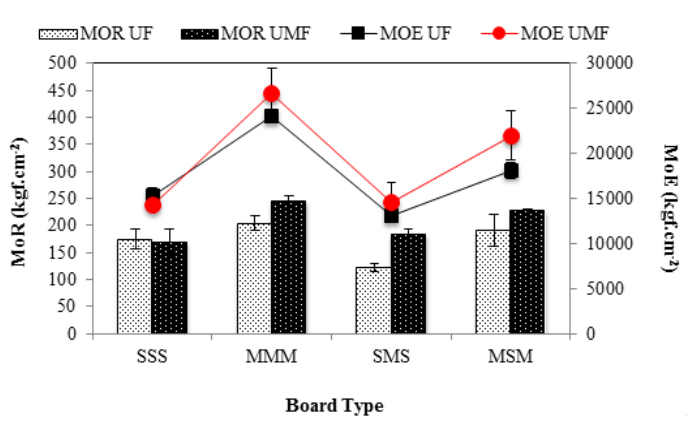

Fig. 5. Modulus of elasticity and modulus of rupture of particleboard.

\subsection{Mechanical Properties}

\subsubsection{Modulus of elasticity (MOE) and Modulus of Rupture (MOR)}

MOE of particleboards ranged 13,149 to 26,638 kgf.cm ${ }^{-2}$ (Fig. 5). The highest and the lowest MOE were presented by MMM and SMS boards, respectively. Homogenous sengon particleboards resulted lower MOE compared to mahogany particleboard. It was influenced by specific gravity of wood and board density. MOE was affected by board density, the highest board density resulted the highest MOE (Subiyanto et al., 2008). Furthermore, the lower specific gravity of wood as surface layers tended to produce the lower bending of board. High wood density showed since in versa. It was proofed by low bending strength of sengon wood as surface layers (Fig. 5). Furthermore, as mentioned before, SR and AR for sengon wood shaving were 136 and 6.1, respectively. Arabi et al. (2011) and Lin et al. (2004) stated that bigger particle size increased the board strength compared to smaller particles. Higher SR value increased the cover area of adhesive in surface 
area, unfortunately the increasing of SR resulted in negative effect on IB of board.

MOE was also influenced by adhesive type and content and particle geometry (Maloney, 1993). According to the Fig. 5, in the similar adhesive content, UMF boards had higher MOE than that of UF board. It is caused by the presence of MF on UMF resin increases bonding quality of particleboard. MF is for exterior application, it has more durability and higher strength properties compared to UF.

Statistical analysis showed that all boards had significant differences to MOE. For UF, DMRT analysis showed that SSS board differed significantly with MMM board, meanwhile for SSS board bonded by UF-MF was significantly difference with MMM and MSM board. The MMM for UF adhesive and MSM for UMF resin fulfills requirement of JIS A 5908 (2003) type 8. It required MOE was up to 20,000 kgf.cm ${ }^{-2}$ (JSA, 2003). Meanwhile, the MMM board using UF-MF fulfills JIS A 5908 (2003) type 13 with MOE is up to $25,000 \mathrm{kgf.cm}-2$ (JSA, 2003).

The MOR of boards was 122 to $246 \mathrm{kgf.cm}{ }^{-2}$ (Fig. 5). Similar trend with MOE was also resulted in the MOR of boards. The highest and the lowest MOR were resulted by MMM and SMS boards, respectively. The presence of mahogany wood shaving can improve MOR. It was due to a high density of mahogany wood compared to sengon. Therefore, the board strength can increase. A high density of wood as surface layer provided higher MOR than that of the others. Referred to the mechanical theo- ry, compared to core layer, surface layer obtains the first and high impact loading. As result, the maximum stress occurred in this layer. Suzuki and Takeda (2000) stated that surface layer properties dominated the bending properties of board. According to Maloney (1993), board with superior strength properties was produced by higher density species. In order to produce the highest bending strength of board, the surface layer became denser than that of the core layer (Bowyer et al., 2003). Utilization of high quality materials for surface layer can improve low quality materials in particleboard. Jossifov (1989) mentioned that the compaction ratio and specific gravity were important variables that affected the bending strength. The compaction ratio had positive linier correlation with bending strength. High compression ratio of board was resulted from high density of woods. The produced board density must be higher than that of wood density, as consequently the bending of board became increase. SR also affected MOR. The SR of mahogany and sengon wood shavings in this research were 153 and 136, respectively. Length and thin particles tend to increase of SR, and it will be able to support higher stress in resulting higher MOR.

Statistical analysis showed that all UMF boards had significant difference to MOE and it was conversely for UF. Similar to MOE, DMRT analysis showed that SSS board had different significant with MMM and MSM board. Overall, the boards had fulfilled JIS A 5908 (2003) that MOR was more than $82 \mathrm{kgf.cm}^{-2}$ 
Apri Heri Iswanto $\cdot$ Janrahman Simarmata $\cdot$ Widya Fatriasari - Irawati Azhar - Tito Sucipto $\cdot$ Rudi Hartono

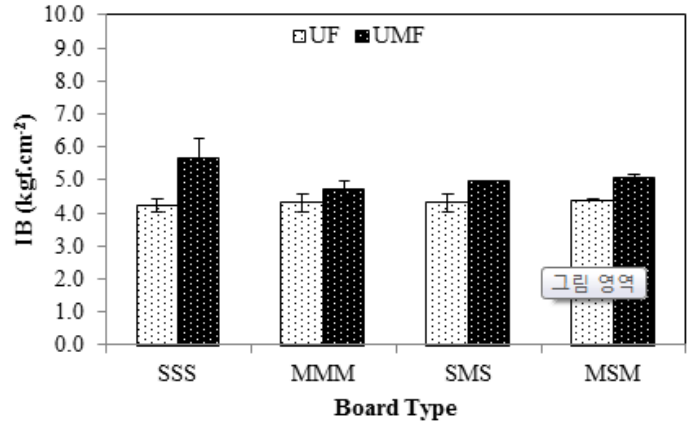

Fig. 6. Internal bond particleboard.

for type 8 (JSA, 2003). Generally, MOR for UMF particleboard met standard for type 18 (greater than $180 \mathrm{kgf.cm}{ }^{-2}$ ). The similar condition was also resulted by mahogany wood shaving as surface layer of UF board.

\subsubsection{Internal Bond (IB)}

According to Fig. 6, IB of particleboards ranged 4.2 to $5.6 \mathrm{kgf.cm}{ }^{-2}$. The highest and the lowest MOE of board were resulted by SSS board using UMF resin and SSS board with UF, respectively. Resin combination resulted higher IB relatively compared to UF. Overall, IB of board met standard. It is affected by acidity effect of wood. Iswanto et al. (2011) reported that sengon and mahogany wood had acidity $(\mathrm{pH})$ of 4.07 and 4.99 respectively. Temperate wood and tropical wood had $\mathrm{pH}$ of 3.3 to 6.4 and 3.7 to 8.2 (Fengel and Wegener, 1984). The acidity was caused by free acid and acid hydrolysis from acetyl group during treatment. It was supported by Nawawi et al. (2005) in which punak (Tetramerista glabra) wood with lower $\mathrm{pH}$ resulted higher IB compared to gerunggang (Cratoxylon arborescens) wood. The increase of $\mathrm{pH}$ caused resistance of UF resin polymerization resulting in low particle bonding (Langum, 2007). Furthermore, $\mathrm{pH}$ was also affected gelatin time at low concentration of catalyst, and this effect would reduce along with increase of catalyst concentration (Xing et al., 2004). UF has better performance in acid condition (Nawawi et al., 2005; Malanit et al., 2009). Overall, IB of board met standard of JIS A 5908 (2003) type 18 requiring IB higher than $3 \mathrm{kgf.cm}$.

\section{CONCLUSIONS}

The utilization of Mahogany wood shavings as the core layer of the particleboard provides better density and thickness swelling than that of sengon. Higher density of Mahogany wood as surface layer affected higher bending strength compared to sengon. The presence of sengon wood shaving actually increased the internal bonding than that of mangium ones. More acidic properties of Sengon wood produced better particle adhesion with adhesive having the optimum performance in acidic condition. UMF resin resulted improvement on dimensional stability and mechanical of particleboard.

\section{ACKNOWLEDGMENTS}

We would like to express my sincerely thanks to Directorate General Higher Education - Ministry of Research, Technology and Higher Education Republic of Indonesia for funding support through to the College Excellent Research Grant 2015. 
Physical and Mechanical Properties of Three-layer Particleboards Bonded With UF and UMF Adhesives

\section{REFERENCES}

Arabi, M., Faezipour, M., Layeghi, M., Enayati, A.A. 2011. Interaction Analysis Between Slenderness Ratio and Resin Content on Mechanical Properties of Particleboard. Journal of Forestry Research 22(3): 461 464.

Bektas, I., Guler, C., Kalaycioglu, H., Mengeloglu, F., Nacar, M. 2005. The Manufacture of Particleboards using Sunflower Stalks (Helianthus annuus 1.) and Poplar Wood (Populus alba L.). Journal of Composite Materials 39(5): 467 473.

Bowyer, J.L., Shmulsky, Haygreen, J.G. 2003. Forest Products and Wood Science - An Introduction. Fourth edition. Iowa (US): Iowa State University Pr. Bufalino, L., Albino, V.C.S., VA, de Sá., Corrêa, A.A.R., Mendes, L.M., Almeida, N.A. 2012. Particleboards Made from Australian Red Cedar: Processing Variables and Evaluation of Mixed-Species. Journal Tropical Forest Science 24(2): $162 \sim 172$.

Febrianto, F., Hidayat, W., Samosir, T.P., Lin, H.C., Soong, H.D. 2010. Effect of Strand Combination on Dimensional Stability and Mechanical Properties of Oriented strand Board Made from Tropical Fast Growing Tree Species. Journal of Biological Science 10(3): 262 272.

Fengel, D and Wegener, G. 1984. Wood-Chemistry, Ultrastructure, Reactions. Walter de Gruyter, Berlin and New York.

Garay, R.M., MacDonald, F., Acevedo, M.L., Calderón, B., Araya, J.E. 2009. Particleboard Made with Crop Residues Mixed with Wood from Pinus radiata. Journal BioResources 4(4): 1396 1408.

Hidayat, W., Sya'bani, M.I., Purwawangsa, H., Iswanto, A.H., Febrianto, F. 2011. Effect of Wood Species and Layer Structure on Physical and Mechanical Properties of Strand Board.
Jurnal Ilmu dan Teknologi Kayu Tropis 9(2): $134 \sim 140$.

Hsu, W.E. 1987. A process for stabilizing waferboard/OSB. In: Proceedings of the Washington State University. Particleboard Symposium 21: 219 236.

Iswanto, A.H., Sucipto, T., Nadeak, S.S. D., Fatriasari, W. 2017. Post-Treatment Effect of Particleboard on Dimensional Stability And Durability Properties of Particleboard Made from Sorghum Bagasse. 1st Annual Applied Science and Engineering Conference. IOP Conf. Series: Materials Science and Engineering 180 (2017) 012015 doi 10.1088/1757-899X/180/1/012015

Iswanto, A.H., Aritonang, W., Azhar, I., Fatriasari, W. 2017. The physical, mechanical and durability properties of sorghum bagasse particleboard by layering surface treatment. Journal of the Indian Academy of Wood Science 14(1): 1-8. DOI:10.1007/s13196-016-0181-7.

Iswanto, A.H., Febrianto, F., Hadi, Y.S., Ruhendi, S., and Hermawan, D. 2013. The Effect of Pressing Temperature and Time on the Quality of Particle Board Made from Jatropha Fruit Hulls Treated in Acidic Condition. Makara Seri Teknology 17(3): $145 \sim 151$.

Iswanto, A.H., Febrianto, F., Hadi, Y.S., Ruhendi, S., Hermawan, D. 2012. Physical and Mechanical Properties of Particleboard Made from Jatropa (Jatropha curcas) Fruit Hulls Reinforced with Wood Particle. Jurnal Ilmu dan Teknologi Kayu Tropis 10(2): 103 111.

Iswanto, A.H., Sucipto, T., Febrianto, F. 2011. Acidity and Buffering Capacity of Some Tropical Wood. Jurnal Ilmu dan Teknologi Hasil Hutan 4(1): $21 \sim 24$.

Iswanto, A.H., Febrianto, F., Wahyudi, I., Hwang, W.J., Lee, S.H., Kwon, J.H., Kwon, S.M., Kim N.H., Kondo, T. 2010. Effect of Pre-treatment 
Apri Heri Iswanto $\cdot$ Janrahman Simarmata $\cdot$ Widya Fatriasari - Irawati Azhar - Tito Sucipto $\cdot$ Rudi Hartono

Techniques on Physical, Mechanical and Durability Properties of Oriented Strand Board Made from Sentang wood (Melia excelsa Jack). Journal of the Faculty of Agriculture, Kyushu University 55(2): $371 \sim 377$.

Japanese Standard Association. 2003. Japanesse Industrial Standard Particle Board JIS A 5908. Tokyo.

Jossifov, N. 1989. Wechselbeziehungen zwischen der Dichte und wesentlichen physikalisch-mechanischen Eigenschaften industriell hergestellter mehrschichtiger Spanplatten aus Hartlaubholz. Holztechnologie 30(4): 200 202.

Kelly, M.W. 1977. Critical literature review of relationship between processing parameters and physical properties of particleboard. USDA For. Serv. Gen. Tech. Rep FPL-10. Forest Products Laboratory, Madison, USA.

Langum, C.E. 2007. Characterization of Pacific Northwest Softwoods for Wood Composites Production. [Thesis]. Washington (US): Washington State University.

Lin, H.C., Huang, J.C. 2004. Using Single Image Multi-Processing Analysis Techniques to Estimate the Internal Bond Strength of Particleboard. Taiwan Journal Forestry Science 19(2): $109 \sim 117$.

Malanit, P., Barbu, M.C., Fruhwald, A. 2009. The Gluability and Bonding Quality of an Asian Bamboo (Dendrocalamus asper) for the Production of Composite Lumber. Journal Tropical Forest Science 21(4): 361 368.

Maloney, T.M. 1993. Modern particleboard and dry-process fiberboard manufacturing. Forest Products Society, Madison. WI.

Moslemi, A.A. 1974. Particleboard. Volume 1: Materials. Southern Illinois University Press, Carbondale.

Nawawi, D.S., Rusman, D., Febrianto, F., Syafii, W.
2005. Bonding Properties of Some Tropical Woods in Relation to Woods Acidity. Jurnal Teknologi Hasil Hutan 18(2): 47 52 .

Pandit, I.K.N., Nandika, D., Darmawan, I.W. 2011. Analysis of Wood Character of Social Plantation Forests. Journal Ilmu Pertanian Indonesia 16(2): $119 \sim 124$.

Rofii, M.N., Yumigeta, S., Suzuki, S., Prayitno, T.A. 2013. Effects of Shelling Ratio and Particle Characteristic on Physical Properties of Three-Layered Particleboard Made From Different Wood Species. Wood Research Journal 4(1): $25 \sim 30$.

Subiyanto, B., Rasyid, E., Gopar, M., Firmanti, A. 2008. Veneer and Thin Plywood Overlaid for Quality Improvement of Particleboard Made of Palm Oil Empty Fruit Bunches (EFB). Journal Tropical Wood Science and Technology 6(1): $17 \sim 20$.

Suzuki, S., Takeda, K. 2000. Production and Properties of Japanese Oriented Strand Board I: Effect of Strand Length and Orientation on Strength Properties of Sugi Oriented Strand Board, Journal of Wood Science 46: 289 295. Winistorfer, P.M., Moschler, W.W., Wang, S., DePaula, E., Bledsoe, B.L. 2000. Fundamentals of vertical density profile formation in wood composites. Part 1. In-situ density measurements of the consolidation process. Wood Fiber Science 32(2): 209 219.

Xing, C., Zhang, S.Y., Deng, J. 2004. Effect of Wood Acidity and Catalyst on UF Resin Gel Time. Holzforschung 58: 408 412.

Yusoff, N.F., Kasim, J., Lias, H., Hussin, M.C., Jasmi, N.F. 2014. Evaluation of 3-Layer Oil Palm Frond Particleboard. International Journal of Latest Research in Science and Technology 3(6): $183 \sim 186$. 